\title{
The importance of protecting unique Romanian landscape values, illustrated by examples of problem solving in other countries
}

\author{
Anna Imola HENNING \\ Szent István University Budapest, Doctoral School of Landscape \\ Architecture and Landscape Ecology, \\ e-mail: henning_imola@yahoo.com
}

Manuscript received Sept. 30, 2016; revised Oct. 25, 2016; Accepted Oct.30, 2016

\begin{abstract}
Nature and landscape protection has gained importance over the past 50 years from the economic, cultural, health, and recreational point of view. The process is closely linked to our civilizational endeavours (such as economic interests, pollution, urbanization, super-intensive agriculture, etc.) that threaten our natural values as well as to the ever more frequent environmental disasters resulting from the above. The continued destruction of our natural and landscape values is not reversible. The aim of this article is to determine the important and urgent professional tasks regarding exploring, documenting, safeguarding, and raising awareness of values. My work wishes to draw attention to the landscape values and deficiencies of Transylvania, working with examples from other countries; by using Romanian examples, I also wish to support my assumption according to which if we want to preserve unique landscapes on the European level we need to act quickly.
\end{abstract}

Keywords: landscape protection, exploration, unique character, landscape element

\section{Introduction}

The European Landscape Convention - signed on October 20, 2000 by Romania - defines landscape assessment as a task for the acceding countries. Analysing the way the Convention was put into practice, it can be stated that in Romania there is much more emphasis on conservation than on the exploration of the landscape, of its parts, and unique characteristics. The definition and practical applications of the terms related to landscape potential, landscape characteristic, landscape shaping, and others pertaining to landscape architecture and protection 
are still not emphatic enough. Landscape protection and development investments, landscape and regional planning, as well as landscape rehabilitation, conservation, and development are in most cases still not carried out by experts. Such phenomena are due - among other things - to the lack of training of landscape architects in Romania.

\section{Materials and methods}

We can conclude that while protecting nature is mainly based on ecological grounds, landscape protection is a more complex, interdisciplinary task as it involves not only the protection of the natural value of landscapes but also that of architectural treasures as well as the cultural heritage of humankind forming the landscape. Protecting the landscape character does not only mean the protection of nature (values created by the individual and society are at least just as important in this respect). "Landscape character is the totality of characteristic features of a landscape or part of a landscape that allows it to be distinguished from other landscapes or parts of landscapes, or makes comparison with other landscapes or parts of landscapes possible. [...] the most important factors in determining landscape character are: character-value natural element groups, landscape use and landscape structure developed over time (even centuries), landscape facilities (the quality of the aspect of the landscape), as well as the traditions and emotions connected with the landscape, as well as their expression in the elements constituting the landscape" [1]. Determining landscape character can be achieved through analyses based on surveys, landscape history research, and field observations of sample areas (Fig. 1.).

The working methods and experiences of field work need to be taught to students in addition to the theoretical background of landscape character analysis in the landscape architect training programme, during field exercises. The students are able to understand the landscape and the most important milestones of landscape development as the result of research, analysis, and field surveys of landscapes and parts of landscapes of different characteristics and scales.

The rural landscapes of small Transylvanian settlements - due to traditional and sometimes still existing landscape use - are particularly rich in elements and methods of use that define the landscape character, that are unique on a global scale, and that differentiate the given landscape from other landscapes of the country and of other landscapes of the larger region. We can pride ourselves on anthropogenic landscapes that are unique in Europe. According to Bertalan Andrásfalvi, human beings not only impoverish or damage nature and biodiversity 
with their lifestyles and by providing the goods needed to stay alive but they can also enrich it [2].

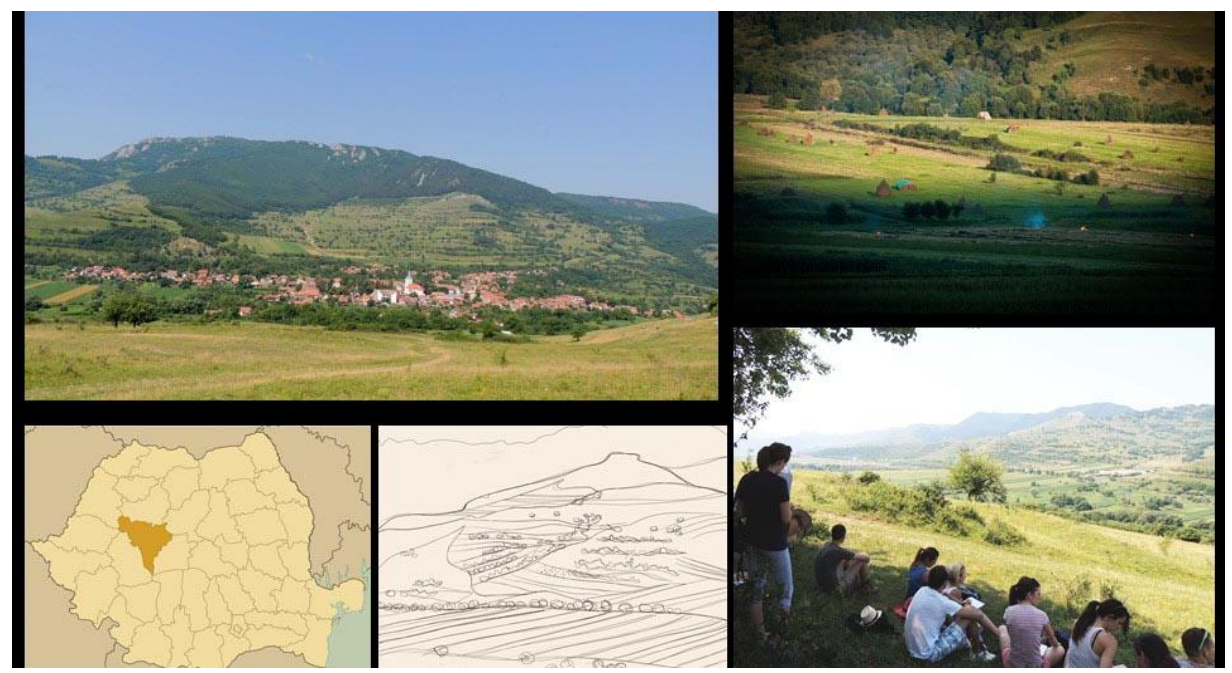

Figure 1. The Landscape architecture students during field practice and landscape character assessment in Torockó (Alba County) (the author's photos).

The landscape elements of the unique landscape values of the history of culture need to be able to strengthen identity. "In today's individualized local society, saving 'traditional' spiritual and natural values might seem anachronistic. The use of the landscape is extreme and is characterized by strict regulations and protection, but it is also market-oriented. [...] The past characteristics of landscape using also underline important relationships in the questions of the relationships between landscape protection and the local population, first regarding ownership, the organization of work and the use of resources" [3].

Landscape elements belonging to the history of culture are not necessarily linked to a place or determine the character of a landscape or a region solely as the elements of traditional agriculture. The details, cyclical changes of a landscape, the experience provided by it, the events taking place in it, the series of landscapes were strongly encoded into our minds during human ontogeny. This also contributes to the fact that the landscape is based on the ethos of the people living there, and this can be the result of a social class (bourgeoisie, aristocrats), of a national minority, or even that of a community living in a certain location [4].

By way of a Transylvanian example, the castle gardens along the River Someș are tied with thousands of threads to the landscape exactly due to the fact that they are perfectly fitted into the landscape as well as because of their links with the landscape, economic embeddedness, social role, etc. It is a real cultural landscape 
due to its characteristic buildings and peculiar landscape structure. It is a good example for the former and current significance of noble residences on landscape architecture [5].

I would like to highlight the issues and deficiencies regarding landscape in Romania with the landscape strategies of two countries I have met and studied in detail. Scotland could be the best example, a direction to follow, while Hungary's inspiring initiative can be stimulating in defining the strategies on landscape protection and preservation of landscape character in Romania, promoting and raising awareness of landscape values.

Róbert Kabai (2010) also highlights the Scottish landscape character assessment programme conducted between 1994 and 1999, which is the first in Europe to grant full coverage and include not only results based on a thorough analysis but also - and perhaps this is the most important aspect - the practical implementations of the results [6].

The Landscape Assessment Guidance constituted the basis of the valuation methodology conducted by the Countryside Commission in 1993, while the presentation of important practical applications as well as the evaluations of results follow the work of Julie Martin Associates and Swanwick from 2003, entitled Overview of Scotland's National Programme of Landscape Character Assessment.

The assessment programme was initiated by the Scottish Natural Heritage, which had a dual objective: creating a landscape database and a practical application of the results. In addition to the Scottish conservation office, external contractors, individuals, and experts of the local governments also participated in the realization of the studies. The landscape architects had an important role in carrying out the studies, and they were helped by ecologists, archaeologists, historians, and town planners with local knowledge.

Beyond the survey conducted throughout the whole territory of Scotland, the aims of the studies are: raising awareness of the importance of the landscape; exploring effects that form the landscape, facilitating building permits and other decisions regarding landscape; promoting strategic connections between the Scottish conservation office, local government authorities, town planning, and use of landscape; establishing a national policy [7]. As a result, the presentation of the factors that form the landscape, the types of landscape characters, the definition and description of landscape character areas, landscape architectural guidelines that help long-term planning and utilization can be found in this work. The most important step, however, is the practical application of the above-mentioned results: the national planning policy makes references in several cases to the topic of landscape character, including the National Planning Policy Guidance 14: Natural Heritage, which provides that the development and settling plans of the 
county are required to include the regulations on preserving and enriching the landscape [6].

The example in Scotland confirms the fact that a landscape character assessment implemented on national level and its practical application can help town planning, the rational utilization of the landscape and of various investments.

The second example to follow for Romania is the Hungarian Cultural Landscape Database programme (TÉKA), supported by the Norwegian Financial Mechanism. As part of the programme, 114 thousand landscapes have been explored in Hungary over two years (the number of the expected values is 150-170 thousand), with a total of 1,066 settlements and 30-50 registered landscapes on every settlement [8]. The program is an interactive online database, which can be improved by anyone with unique landscapes examined by a specific set of criteria, after which an expert will overlook the inserted data and accept them if they meet the criteria. Thus, the database is constantly growing with high efficiency.

\section{Results and discussions}

Intact agricultural landscapes can still be found in Romania and in some neighbouring countries, in mountainous regions. The biological diversity and the preserved landscape culture are outstanding even in international context, and it can be considered a significant landscape value. The Transylvanian and Swedish methods applied concerning livestock and harvesting appeared to be similar; therefore, our landscapes have been researched often by Scandinavians. The uniqueness of the Transylvanian countryside is outstanding on international level, and it has served as an example to follow and a reference in the preservation and reconstruction of the Swedish agricultural landscapes (this is confirmed by a study carried out in 2006, published in 2007 KUNGL. SKOGS- OCH LANTBRUKSAKADEMIENS TIDSKRIFT a: Valuable Agricultural Landscapes - the Importance of Romania and Scandinavia for Europe, published by the Royal Swedish Academy of Agriculture and Forestry in Stockholm.

The Romanian landscapes have one of the richest biological diversity in Europe, especially due to the large pastures of Transylvania, close to nature (Fig. 2.). At the same time, as compared with other countries, the number of preserved landscapes is higher in Romania. The land use, the old traditional methods, and the peasantry as creator of popular culture had not been assessed until they nearly disappeared in some countries. The intensive, mechanized, and overly chemical agriculture led to marginalization, and this process had its negative effects especially on the rural landscape in the case of mown meadows. 


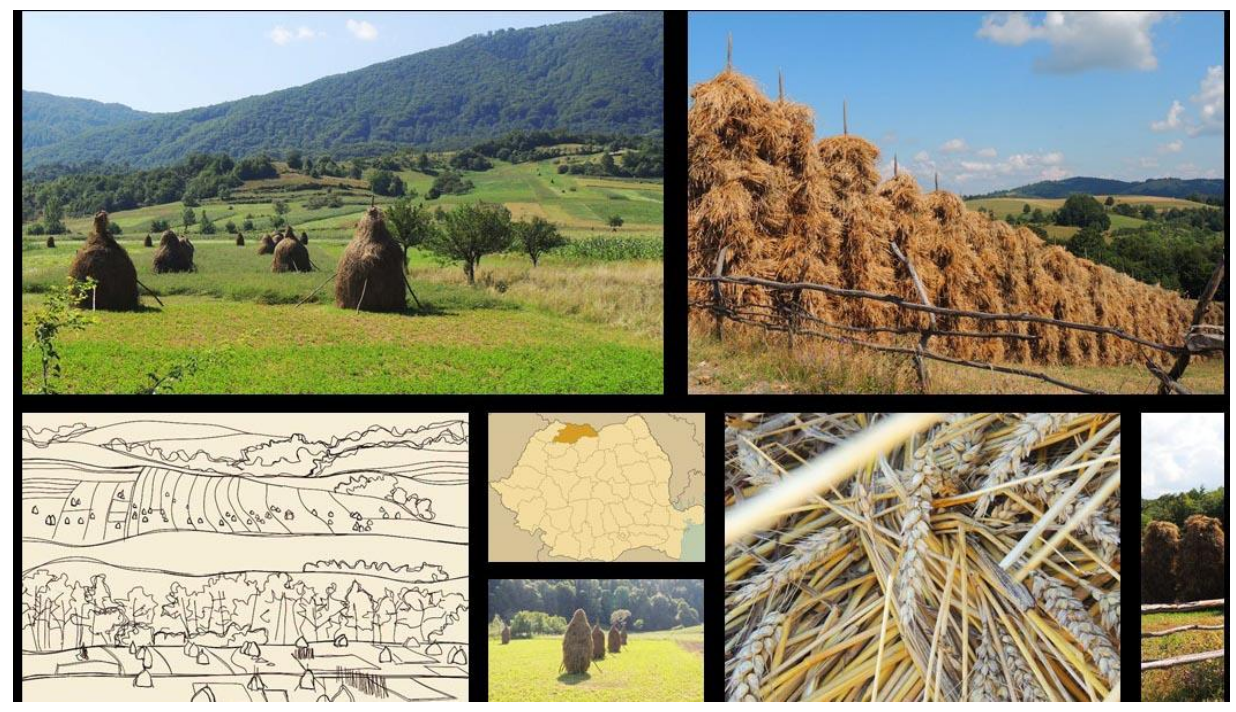

Figure 2. The unique landscape character of Maramureș County (the author's photos).

\section{Conclusion}

In Romania, the legal background of landscape protection barely offers any help at all. Some of them are the European Landscape Convention, the lawn law's conservationist aspect (Legea fondului funciar $n r$. 18/1991, overridden by the Emergency Regulation 34/2013, Ordonanţa de Urgență nr. 34/2013 privind organizarea, administrarea şi exploatarea pajisstilor existente, which came into force on 13.05.2013), the forestry law (Codul Silvic din 2008, which came into force on 30.03.2008.), and, of course, the law regulating the settlements' area redevelopment: General Urbanistic Plan - PUG (Plan Urbanistic General, Legea 350/2001, completed by Legea 289/2006, which entered into force on 07.07.2006), and the Urbanistic Zonal Plan - PUZ (Plan Urbanistic Zonal 350/2001, which entered into force on 07.06.2001, with its subsequent amendments), which mostly regulates construction and urban development in urban areas.

As for the questions about landscape, using the term cultural landscape has become fashionable, but in many cases "cultural landscape" is followed by negative examples. The number of landscape character assessments carried out by professionals has proven to be insufficient. Promoting sensitivity regarding the category of landscape and human-scale landscape management as well as strengthening the local character and identity are considered important priorities. 


\section{References}

[1] Csima, P. (2008), Tájvédelmi szabályozás a településrendezési tervekben. In: Csorba, P., Fazekas, I. (eds), Tájkutatás-tájökológia, Meridián Alapítvány, Debrecen, 401-408.

[2] Andrásfalvy, B. (2006), Biofília, az élő természettel való kapcsolat. In: Selmeczy Kovács, A. (ed.), Lélek és élet. Ünnepi kötet S. Lackovits Emöke tiszteletére. Veszprém Megyei Múzeumi Igazgatóság, Veszprém, 134-138.

[3] Máté, G. (2007), Tájvédelem, hagyomány, helyi társadalom (A tájhasználati aktualitás kérdései egy mecseki aprófalu példáján). Tájökológiai Lapok 5(2), 261.

[4] Fekete, A. (2012), Az erdélyi kertmüvészet - Szamos menti kastélykertek. Müvelödés Mühely, Kolozsvár, 121, 7-9.

[5] Fekete, A. (2013), Designed visual connections in the Transylvanian landscape. Transsylvania Nostra 7(26), 39-48.

[6] Kabai, R. (2010), Skócia tájkarakter felmérése és az eredmények gyakorlati hasznosítása. Tájökológiai Lapok 8(1), 97-109.

[7] Julie Martin Associates - Swanwick, C. (2003), Overview of Scotland's National Programme of Landscape Character Assessment. Scottish Natural Commissioned Report F03 AA307. Website of Scottish Natural Heritage: http://www.snh.gov.uk.

[8] Kollányi, L. (2012), A TÉKA projekt eredményei. V. Magyar Tájökológiai Konferencia, Sopron 2012.08.25-27. Website:

http://www.emk.nyme.hu/fileadmin/dokumentumok/emk/evgi/TajokologiaiKonferencia2012/El oadasok/VI._szekci\%C3\%B3/Koll\%C3\%A1nyiL_tajokologia_sopron_2012.pdf. 